\title{
Hepatitis E Virus: Foodborne, Waterborne and Zoonotic Transmission
}

\section{Danielle M. Yugo and Xiang-Jin Meng *}

Department of Biomedical Sciences and Pathobiology, College of Veterinary Medicine, Virginia Polytechnic Institute and State University, 1981 Kraft Drive, Blacksburg, VA 24061, USA; E-Mail: mydan12@vt.edu

* Author to whom correspondence should be addressed; E-Mail: xjmeng@vt.edu; Tel.: +1-540-231-6912; Fax: +1-540-231-3414.

Received: 2 July 2013; in revised form: 20 August 2013 / Accepted: 3 September 2013 / Published: 25 September 2013

Abstract: Hepatitis E virus (HEV) is responsible for epidemics and endemics of acute hepatitis in humans, mainly through waterborne, foodborne, and zoonotic transmission routes. HEV is a single-stranded, positive-sense RNA virus classified in the family Hepeviridae and encompasses four known Genotypes (1-4), at least two new putative genotypes of mammalian HEV, and one floating genus of avian HEV. Genotypes 1 and 2 HEVs only affect humans, while Genotypes 3 and 4 are zoonotic and responsible for sporadic and autochthonous infections in both humans and several other animal species worldwide. HEV has an ever-expanding host range and has been identified in numerous animal species. Swine serve as a reservoir species for HEV transmission to humans; however, it is likely that other animal species may also act as reservoirs. HEV poses an important public health concern with cases of the disease definitively linked to handling of infected pigs, consumption of raw and undercooked animal meats, and animal manure contamination of drinking or irrigation water. Infectious HEV has been identified in numerous sources of concern including animal feces, sewage water, inadequately-treated water, contaminated shellfish and produce, as well as animal meats. Many aspects of HEV pathogenesis, replication, and immunological responses remain unknown, as HEV is an extremely understudied but important human pathogen. This article reviews the current understanding of HEV transmission routes with emphasis on food and environmental sources and the prevalence of HEV in animal species with zoonotic potential in humans. 
Keywords: hepatitis E virus; HEV; zoonosis; animal reservoir; foodborne transmission; zoonotic transmission; waterborne transmission

\section{Introduction}

Hepatitis E virus (HEV), the causative agent of hepatitis $\mathrm{E}$ in humans, is an important public health disease in many parts of the World [1-4]. Transmission is primarily via the fecal-oral route through contaminated food or water [5]. In developing countries in Asia and Africa, poor sanitation conditions lead to outbreaks of acute hepatitis E; however, sporadic and autochthonous cases of hepatitis E also occur throughout many industrialized countries in Europe, Asia, and North America [6,7]. In humans, the mortality rate ranges from $0.5-4 \%$ for immunocompetent individuals, however, mortality in HEV-infected pregnant women can reach up to $20 \%$ and immunocompromised individuals may develop a chronic HEV infection [8,9]. In addition to humans, HEV has been identified in numerous other animal species including wild and domestic swine, deer, chicken, mongoose, rat, ferret, fish, and rabbits with an ever-expanding host range $[1,7,10]$. Hepatitis $\mathrm{E}$ is now a recognized zoonotic disease with swine and likely other animals serving as the reservoir for human infections [1,8]. Food safety associated with HEV contamination is an important public health concern with the recent identification of infectious $\mathrm{HEV}$ in meat and meat products and resultant sporadic cases of foodborne hepatitis $\mathrm{E}$ in the human population [3,11-14]. This review article discusses the public and environmental health concerns and risks associated with HEV infection with an emphasis on foodborne and zoonotic transmissions.

\section{HEV Classification and Biology}

\subsection{Classification}

HEV belongs to the genus Hepevirus in the family Hepeviridae and consists of four recognized genotypes and at least two putative new genotypes [5]. Genotype 1 causes large outbreaks of acute hepatitis $\mathrm{E}$ in humans in Asia. Genotype 2 causes outbreaks in humans and includes one Mexican strain and several African strains. Genotype 3 is associated with sporadic, cluster, and chronic cases of hepatitis E in humans, mostly in industrialized countries. Genotype $3 \mathrm{HEV}$ is known to be zoonotic and has also been isolated from domestic and wild swine, deer, mongoose, rats, and rabbits [12,15-19]. Genotype $4 \mathrm{HEV}$ is also zoonotic and is associated with sporadic cases of hepatitis $\mathrm{E}$ in humans and infects wild and domestic swine and reportedly cattle and sheep [1,5].

Avian HEV from chickens only shares approximately 50\% nucleotide sequence identity with mammalian HEV; therefore, avian HEV likely represents a separate genus [20]. The genus Avihepevirus has recently been proposed to include all three known genotypes of avian HEV in chickens (Genotype 1 in Australia and Korea, Genotype 2 in the United States, and Genotype 3 in Europe and China) $[1,21,22]$. The recently-identified rat HEV shares approximately $59.9 \%$ and $49.9 \%$ sequence identities with human and avian HEV, respectively, while the ferret HEV shares the highest sequence identity with rat HEV at $72.3 \%$ [18,23]. The genus Orthohepevirushas has recently been proposed to encompass both the rat and ferret strains of HEV as well as a novel wild boar HEV strain 
recovered in Japan that differed from the known Genotypes 1-4 HEV isolates by 22.6-27.7\% in nucleotide sequence identity [1,24]. A bat HEV was recently identified from African, Central American, and European bats, and due to high sequence diversification from known HEV isolates at $47 \%$ amino acid sequence identity, the bat HEV forms a novel phylogenetic clade [25]. The genus Chiropteranhepevirus has been proposed to include all variants of the bat HEV [1]. Finally, a strain of HEV was also identified in cutthroat trout in the United States with only 13-27\% sequence homology with mammalian or avian hepeviruses leading to a proposal of another tentative genus, Piscihepevirus, within the Hepeviridae family [1,26]. The nomenclature of HEV will need to be modified in the near future as more genetically-divergent animal strains of HEV are identified.

\subsection{HEV Biology}

The genome of HEV is a single-stranded, positive-sense, RNA molecule of approximately $7.2 \mathrm{~kb}$ in size $[3,4,27]$. The genome consists of three open reading frames (ORFs), a $5^{\prime}$ non-coding region (NCR), and a 3' NCR [10]. ORF1 encodes non-structural proteins with conserved domains functioning as a methyltransferase, helicase, RNA-dependent RNA polymerase (RdRp), and a papain-like cysteine protease [20,28]. In addition, a hypervariable region (HVR) within ORF1 may play a role in viral pathogenesis despite being shown to have no influence on viral infectivity [29]. ORF2 encodes the immunogenic capsid protein, which interacts with 3' viral genomic RNA for encapsidation and contains an endoplasmic reticulum signal peptide and $3^{\prime} \mathrm{N}$-glycosylation sites [30,31]. ORF3 encodes a small phosphoprotein with incompletely understood functions; however, the association with cytoskeleton and its necessity for in vivo viral infection in rhesus macaques suggests that ORF3 plays a role in viral replication and assembly [20,32,33].

Avian HEV is genetically related to mammalian HEV with conserved genomic organization and function despite a $600 \mathrm{bp}$ sequence deletion [34-36]. The capsid protein of avian HEV contains both unique and conserved antigenic epitopes in comparison to the human and swine HEV capsid proteins [37].

The HEV replication cycle is currently not well understood due to a lack of an efficient cell culture system [38]. Heparin sulfate proteoglycans (HSPGs) likely act as receptors for the attachment of the viral capsid protein, and the heat shock cognate protein 70 may be involved in HEV entry into the cell [38]. Following uncoating in the cell, the HEV genomic RNA is likely utilized to translate the non-structural proteins and the viral RdRp is used to produce progeny virus [38]. Both ORF2 and ORF3 are translated from a bicistronic subgenomic RNA [32,39]. The negative-sense HEV RNA indicative of virus replication is detectable in hepatic and extrahepatic tissues of experimentally-infected rhesus macaques and swine $[38,40]$. Post-translational processing of proteins and mechanisms of virus assembly and release have yet to be fully elucidated, and the viral-host interactions leading to a disease state are also poorly understood [5,20,38]. Development of a robust cell culture system to efficiently propagate $\mathrm{HEV}$ in the future should be a priority, and will facilitate our understanding the biology of this important virus. 


\section{HEV Pathogenesis}

\subsection{HEV Infection in Humans}

In humans, HEV causes an acute icteric disease that varies in symptoms from subclinical to fulminant hepatitis [4]. The asymptomatic patient typically clears the virus rapidly, while the symptomatic patient experiences clinical signs including anorexia, hepatomegaly, myalgia, jaundice and sometimes abdominal discomfort, nausea, vomiting, and fever [5,41]. In immunocompromised patients such as organ transplant recipients, lymphoma and leukemia patients, or patients with HIV infection, the course of disease may progress to a chronic state with cirrhosis of the liver and persistence of viral shedding [42-46]. Of particular concern is the ability for HEV-infected immunocompromised individuals to develop clinical disease well after the initial exposure [44-47]. Currently, chronic HEV infection in immunocompromised individuals is an emerging and significant clinical problem. Future studies are warranted to identify the immunological correlates and host factors leading to chronicity.

The typical infection begins with an incubation period of 2 weeks to 2 months and a transient viremia followed by viral shedding in the feces, disappearance of viremia with the onset of clinical signs, and regression of viral shedding with potential jaundice setting in around 2-3 weeks into the infection [46]. The severity of HEV infection is considered dose-dependent and host factors such as concurrent hepatic disease or alcohol overuse may also contribute to the disease course [41]. In studies from France, Germany, the United Kingdom, and the United States, middle-aged, elderly men were more likely to experience autochthonous HEV infection; however, the underlying host factors have not been understood [48-51]. Of major concern is the relationship between pregnancy and increased mortality rates up to $20 \%$ in HEV endemic regions; however, this relationship appears to be geographically dependent and may be associated with other underlying factors such as virus genotype or concurrent infections with other pathogens [4,20,52-54]. Complications with concurrent HEV infection during pregnancy include death of both the mother and fetus, abortion, premature birth, and death of the baby shortly after birth [55]. Vertical transmission from the mother to fetus was reported in 33\% of cases and HEV RNA was reportedly detected in human colostrum as well [56,57]. Unfortunately it is not understood why pregnancy resulted in severe hepatitis E manifestation. Understanding the mechanisms of pregnancy-associated severe hepatitis E, especially fulminant hepatitis $\mathrm{E}$, in the future will help devise effective preventive measures against this disease.

Genotypes 1 and $2 \mathrm{HEV}$ strains are restricted to the human population, while Genotypes 3 and 4 HEV strains infect both humans and other animals with zoonotic transmission routes. Human to human transmission of $\mathrm{HEV}$ is considered rare; although, blood-borne transmission has been reported via blood transfusion [20,58-60]. A comparative study of Genotype 3 and $4 \mathrm{HEV}$-infected individuals in Japan revealed that Genotype $4 \mathrm{HEV}$ is associated with a higher level of alanine aminotransferase (ALT), higher prevalence of clinical infection, higher level of total bilirubin, higher level of viremia, more frequent fulminant hepatitis development, and overall a more aggressive hepatitis [48]. The mechanisms of cross-species HEV infection remain poorly understood. Identification of both the viral genetic elements and host factors that are important for cross-species HEV infection will be the key for devising strategies to prevent and control zoonotic HEV infections. 


\subsection{HEV Infection in Animals}

Natural and experimental HEV infections in swine (Genotypes 3 and 4) result in a subclinical course of infection with only mild microscopic lesions in the liver and associated lymph nodes [61,62]. Viremia lasts 1-2 weeks with fecal virus shedding lasting 3-7 weeks [7,61,62]. HEV infection in swine is age-dependent with up to $86 \%$ of the pigs infected by 18 weeks of age [63]. Additional studies from the United Kingdom, Spain, and Japan further demonstrated that the highest fecal virus shedding occurred by 10-12 weeks, 13-16 weeks, and 1-3 months of age, respectively [64-66]. Seroconversion to HEV antibodies in swine occurs following the typical waning in maternal antibody levels around 8-10 weeks of age first with IgM anti-HEV antibodies peaking in conjunction with fecal viral shedding followed by IgG anti-HEV antibodies peaking in conjunction with clearance of virus from the feces [20,64-66].Transmission between swine is fecal-oral with large amounts of infectious HEV being shed in the feces, and direct contact between animals, with other animals' excreta, and with potentially contaminated water sources in swine facilities contributes to transmission within a herd [7,67-70]. Although HEV infection in pigs does not pose a major economical concern in swine production, the risk of zoonotic transmission to humans is an important public health concern. Therefore, development of an effective vaccine to immunize susceptible swine herds in the future will minimize the risk of zoonotic infection and improve pork safety.

Avian HEV Genotypes 1-3 carry a slightly different course of infection with a high level of subclinical infection in flocks and mortality rates up to $0.3-1.0 \%[36,71,72]$. Clinical signs may include egg drop in some flocks up to $20 \%$, enlargement of the liver and spleen, and acute death of affected birds [73]. Post-mortem evaluations show enlarged, hemorrhagic, and focally necrotic livers, inflammatory cellular infiltrations in the liver tissue, serosanguinous abdominal fluid, and regressing ovaries in some affected birds [73,74]. It appears that avian HEV does not infect humans, and thus is not a concern for food and environmental safety. Nevertheless, more studies are needed to fully assess the potential of avian HEV cross-species infection.

\section{Epidemiology of HEV Infection}

HEV is considered hyperendemic in many developing countries such as India, Bangladesh, Egypt, Mexico, and China. Hyperendemic countries carry an HEV prevalence of $25 \%$ of all non-A, non-B, acute hepatitis cases or have experienced a major waterborne outbreak of hepatitis $\mathrm{E}$ according to the Centers for Disease Control and Prevention [75]. HEV is considered endemic where there is a prevalence of less than $25 \%$ of all reported non-A, non-B acute hepatitis [75]. Endemic countries include much of Western Europe, the United States, New Zealand, many countries in South America, much of Asia, and the Middle East [75-77]. Trends throughout the World point to continued high anti-HEV seroprevalence and HEV infection likely due to increases in interest, awareness and surveillance efforts as well as increased spread among known animal reservoirs and hosts [20,75-81]. Seroprevalence reports vary dramatically from country to country and study to study with some studies reporting overall declines in seroprevalence over time, while other yield continued high levels of seroprevalence $[80,82,83]$. Prevalence of anti-HEV IgG tends to increase with age, especially in men [80,84-87]. Humans and other animals excrete a considerable amount of virus early in the acute phase of HEV infection and likely 
contribute to maintain the cycle of endemicity [76]. The lack of a standardized serological assay further complicated the interpretation of the sero-epidemiological data. Therefore, development of a FDA-approved diagnostic assay for HEV should be a priority in the future.

\section{Environmental Contamination and Waterborne Transmission}

\subsection{HEV Transmission from Sewage and Animal Manure Run-off}

HEV is typically transmitted via fecal-oral route within an animal species, from animals to humans in infectious body fluids, and from contaminated food or water sources to humans and other animals. Inadequate disposal and treatment of sewage and contamination of drinking and irrigation water lead to the many epidemics in developing countries $[2,88,89]$. Increased rates of human HEV infection in Turkey and certain countries in Southeast Asia are associated with utilizing untreated river water for everyday tasks such as bathing, drinking, and disposal of waste products [90-93]. Environmental catastrophes and annual flooding are also associated with elevated HEV attack rates especially in regions where river, pond, or well water use is prevalent [10,92-94]. In both industrialized and developing countries, raw sewage water has been shown to contain infectious HEV strains that are closely related to the strains circulating in humans (Genotypes 1 and 2) and other animals (Genotypes 3 and 4) [95-99]. In The Netherlands, Genotype 3 HEV RNA was detected in river water which likely originated from sewage [100]. Run-offs from animal facilities such as hog operations have been implicated in human HEV infections with the detection of infectious Genotype $3 \mathrm{HEV}$ in the animal manure and wastewater $[100,101]$.

Professionals working in close proximity to swine, swine manure, or sewage may become infected with HEV during occupational activities [70,100,102-104]. For example, swine workers in Valencia, Spain were found to be 5.4 times more likely to be positive for anti-HEV IgG than those not exposed to swine [104]. Utilizing a Bayesian model to account for imperfections in sero-assays leading to differences in the interpretation of serology results, Bouwknegt et al. [103] found that approximately $11 \%$ of swine veterinarians, $6 \%$ of non-swine veterinarians, and $2 \%$ of the general population were positive for anti-HEV antibodies. Variation in assays, validity of serologic tests for determining HEV prevalence, the lack of standardized diagnostic tools, the potential for multiple routes of transmission, and incompletely understood transmission routes particularly in small defined populations lead to difficulty in assessing the exact risk factors for HEV infection [105,106]. For example, Vulcano et al. [107] identified male housekeepers and specific pig breeders as carrying a higher prevalence of IgG anti-HEV seropositivity than previously identified in Italy and found a 5.5\% seropositivity in subjects from Rieti in comparison to $2.5 \%$ from Rome, despite an overall lack of association with swine contact. In addition, pig farmers and the general population in Sweden were found to have $13 \%$ and $9 \%$ seropositivity respectively, which was higher than previously reported for populations in Europe (1-9\%) and contributes to uncertainty in our current knowledge of transmission routes and risk factors for HEV infection [108]. Again, standardized serological and molecular diagnostic tests are in critical need for the study of HEV transmission and prevalence. During natural contact routes of transmission, HEV RNA is also detectable in the urine of infected swine, which likely contributes to the ease of spread in confined swine operations and may pose as an alternate route of exposure for humans [109]. Contaminated water 
and sewage may serve as sources for HEV infection in both humans and other animals. Current research indicates the potential for transmission through these sources; however, further analysis of these sources in regards to all genotypes of HEV will better assess the overall public health risk.

\subsection{Surface Water Contamination and Transmission of HEV}

Surface water is easily contaminated by stable fecal-shed viruses such as HEV and acts as a public health hazard [110]. The quality of surface water directly affects populations utilizing the source since drinking water, and intensive farming practices lead to higher detection rates of viruses within these sources [110,111]. In Canada, HEV Genotype 3 detected from field-grown strawberries shared 99\% nucleotide sequence identity with local swine HEV strains [112,113]. In Slovenia, Genotype 3 HEV was recovered from surface waters as well as from $20 \%$ of fecal samples in local pig farms [114]. Typical irrigation practices allow HEV and other enteric and hepatic viruses to impact surface water quality and elevate the potential for human exposure to pathogens [115,116]. Contaminated produce may serve as a source for autochthonous HEV cases in non-endemic regions [112,117]. In all cases of HEV detection in water or produce, the contamination levels were not assessed for further infectivity of humans or animals. The ability to recover infectious virus both from the local pig farms, the surface waters, and from produce receiving contaminated water would indicate that the virus is stable enough to be transmitted in these sources. Therefore, further infectivity studies should be done to assess the ability to transmit and cause infection especially in cases where the virus contamination levels are low.

\subsection{Coastal Water Contamination and Transmission of HEV}

Coastal waters may also be contaminated by HEV leading to accumulation of the virus in the digestive tissues of shellfish, which poses a risk of human infection through ingestion. Most often, mussels, cockles, and oysters are eaten raw or slightly cooked, and HEV is stable in both alkaline and acidic environments, frozen for more than 10 years, and remains infectious at up to $60{ }^{\circ} \mathrm{C}$, suggesting that a raw, rare-cooked, or slightly steamed contaminated seafood may transmit HEV to consumers $[118,119]$. Shellfish have been implicated in an outbreak of HEV occurring aboard a cruise ship in European waters and HEV has been identified in commercial mussels obtained from three European countries (Finland, Greece, and Spain) [120,121]. In Scotland, 92\% of bivalve mussels collected were tested positive for HEV RNA with the viral sequences clustering with Genotype 3 human and swine HEV [122]. Case reports of hepatitis E in England, Italy, and France reveal shellfish consumption as a common source risk factor for HEV infection [79,123,124]. In addition, Genotype 3 swine HEV has been detected in shellfish in Korea and Japan [125-127]. Travelers to hyperendemic and endemic regions of the world are at an increased risk of acquiring HEV infection from contaminated water and seafood, but industrialized countries are not exempt [77].

\section{Foodborne Transmission and Food Safety}

The meat products from HEV-infected reservoir animal species are capable of transmitting HEV to humans and are a public health concern $[75,76,88]$. HEV primarily replicates in the liver of infected animals; however, extra-hepatic sites of HEV replication have also been demonstrated in the 
gastrointestinal tissues, mesenteric and hepatic lymph nodes, and spleen [20]. In addition to the liver tissues, HEV RNA has been detected from the stomach, kidney, salivary glands, tonsils, lungs, and multiple muscle masses of pigs and chickens when inoculated intravenously [128-130].

Consumption of undercooked or raw organs or tissues from infected swine has been linked to numerous cases of hepatitis E worldwide. For example, three cases of hepatitis E in Japan were associated with the consumption of undercooked or raw pork presumably from the same barbeque restaurant [131]. Nine of ten clinical cases of hepatitis E from 2001 to 2002 had a history of consuming undercooked pork 2-8 weeks before the onset of clinical signs and $1.9 \%$ of pig livers tested from local groceries in Hokkaido, Japan were positive for Genotype 3 or 4 HEV RNA [13]. Consumption of pig liver or intestines is considered as a risk factor for HEV infection [131]. Cases of hepatitis E in Japan were also linked to the consumption of contaminated wild boar meat [132-135]. Wild boar populations in Italy and South-eastern France had detectable levels of HEV RNA in $2.5 \%$ of liver samples and $25 \%$ of bile samples, respectively $[136,137]$. Boar meat consumption was positively associated with HEV infection in a case-control study in Germany [138]. Cases of acute hepatitis E associated with Genotype $4 \mathrm{HEV}$ have been confirmed in South Korea, presumably due to the consumption of raw wild boar bile juice [139]. Human patients with acute HEV infections in France were linked to the consumption of figatellu sausage (Corsican raw pig liver dish). The HEV sequences recovered from the figatellu products in local grocery stores were essentially indistinguishable from the viral sequences recovered from the human patients, thus providing compelling evidence for foodborne HEV transmission [11,140]. The HEV present in the pig liver sausage from manufacturers in France was shown to be infectious utilizing a 3D HEV cell-culture system [141]. Commercial pig livers tested in the United States, Germany, and The Netherlands also carried detectable levels of HEV RNA in 11\%, $4 \%$, and $6.5 \%$ of the samples tested, respectively [142-144]. At slaughterhouses in Bavaria, Germany, $68.6 \%$ of the serum samples and $67.6 \%$ of meat juice samples were tested seropositive for HEV antibody, indicating animal exposures to HEV prior to slaughter [145]. In Italy, an overall $87 \%$ anti-HEV seropositivity was detected in slaughterhouse swine and $64.6 \%$ were positive for HEV RNA indicating both a high level of exposure to HEV and a similarly high level of active virus infection at the time of slaughter [146]. Similar investigations of pork production chains in the Czech Republic, Spain, and the United Kingdom revealed detectable, infectious $\mathrm{HEV}$ at both processing locations and point of sale [147]. Genotype $4 \mathrm{HEV}$ has also been identified in a small percentage of pig livers collected from markets in India and carry a 90-91\% nucleotide sequence identity with the local swine HEV isolates [148]. Other reports identify Indian strains of Genotype 4 swine HEV as genetically distinct from Genotype 1 human HEV strains circulating in the region further convoluting the route of transmission [149]. Human consumption of Genotype $4 \mathrm{HEV-contaminated} \mathrm{pork} \mathrm{livers} \mathrm{leading} \mathrm{to}$ disease has not yet been reported in India, which may be due to differing culinary habits $[11,140]$. It is likely that the Genotype 4 swine HEV in India does cause sporadic cases of acute hepatitis E in humans through zoonotic infection, although such rare and sporadic cases of Genotype 4 hepatitis E may be masked by the more prevalent and explosive form of Genotype 1 hepatitis E in India.

In addition to pork, game meats such as deer have also been implicated as sources for HEV transmission to humans following the detection of near identical HEV sequences from leftover Sika deer meat and four hepatitis E patients in Japan who previously consumed the deer meat as sushi $[14,20,150]$. A locally caught wild deer carried a nearly identical HEV isolate that was later 
confirmed in local wild boar populations in Japan as well [150]. Sashimi style deer meat is usually consumed in Japan where a case-control study attributed raw deer meat as a risk factor for anti-HEV seropositivity after identifying a positive association between deer meat consumption and a previous case of hepatitis E [14,151]. Elevated risks indicate that within this defined case-control population, those who consumed raw deer meat were more likely to be positive for HEV antibodies indicating exposure to the virus, while those who did not consume the deer meat had a lower level of exposure based on seropositivity [14,151]. Consumption of game meats including wild boar, deer, and hare was independently associated with HEV infection in organ transplant recipients in France with an odds ratio of 2.32 [152]. Combined, these studies clearly identify wild and domestic pork products and game meats as sources for human HEV infection and implicate foodborne transmission as a common route for HEV infection.

\section{Known and Potential Animal Reservoirs}

A number of animals are known to serve as the natural hosts and reservoirs for HEV. HEV has been genetically identified from rat, wild boar, domestic swine, mongoose, rabbits, chickens, ferrets, cutthroat trout, bats, and deer [17-19,23,25,26,34,61,139,153]. Anti-HEV antibodies have been detected in a number of other animal species including cattle, sheep, and goats with the potential to carry novel strains of HEV $[1,154]$. With the advance of modern molecular biology techniques such as metagenomics and pyrosequencing, it is expected that the host range of HEV will expand and novel strains of HEV will be identified from other animal species in the near future.

\subsection{HEV in Avian Species}

Avian HEV was identified as such in 2001 from chickens with Hepatitis-Splenomegaly (HS) syndrome in the United States [34]. Likewise, Big Liver and Spleen Disease virus (BLSV) in Australia presented similarly with an approximately $80 \%$ nucleotide sequence identity to avian HEV $[34,73]$. These two previously identified syndromes (HS and BLS) are assumed to be caused by variant strains of the same virus, avian HEV, which now encompasses three distinct, but related genotypes worldwide $[24,73,155,156]$. In the United States, an estimated $71 \%$ of chicken flocks and $30 \%$ of individual chickens are positive for avian HEV [36]. Avian HEV infection in chickens is age-dependent with $17 \%$ of seropositive chickens under 18 weeks of age and $36 \%$ of seropositive adult chickens [36,157]. Avian HEV has been shown to cross species barriers and infect turkeys [71]. It is currently unknown, however, whether avian HEV is capable of transmission to humans or other mammalian species; although, rhesus monkeys and mice are not susceptible to infection by avian HEV under experimental conditions $[1,73]$.

\subsection{HEV in Domestic and Wild Swine Species}

Since its discovery in domestic swine in the United States in 1997, swine HEV strains have been identified worldwide in both domestic and wild swine with widely variable prevalence [11,61]. Studies of prevalence across Japan revealed that anti-HEV antibody is present in $93 \%$ of all domestic swine farms tested and that all swine HEV isolates belong to either Genotype 3 or $4[24,48,158,159]$. Prevalence of 
anti-HEV antibodies in wild boars in Japan is also widely variable ranging from $4.5 \%$ to $34.3 \%$ based on geographic regions with Genotype 3 or 4 HEV RNA detection rates ranging from $1.1 \%$ to $13.3 \%$ [48]. In The Netherlands, domestic swine farms carried a prevalence of 55\% for HEV RNA in the feces, while $86.2 \%$ and $47.1 \%$ of 18 week-old pigs in Canada shed HEV virus in feces and serum, respectively, with a declination as the pigs aged [63,160]. In Spain, the prevalence of anti-HEV antibodies on commercial swine farms reached $98 \%$, while the anti-HEV prevalence in New Zealand, Laos and Brazil is 90\%, 46\% and 81\%, respectively [20,161-164]. The anti-HEV seropositivity in wild boars varied from $17-50.3 \%$ with HEV RNA detected in up to $25 \%$ of samples in Germany, Italy, Spain, Australia, and Hungary [15,136,137,165-167]. In the United States, swine HEV infection in pig farms is also widespread, and the majority of pigs became seropositive to HEV antibodies at approximately 3 months of age [61]. It appears that Genotype 3 or $4 \mathrm{HEV}$ infection in pigs is widespread in the pig population worldwide, thus raising a concern for zoonotic infection and pork safety.

\subsection{HEV in Deer}

Deer have been implicated both acting as animal reservoirs for HEV and acting as vehicles for human infection [12,14,20,150]. The Sika and Yezo deer in Japan carried a 3\% and 35\% anti-HEV seroprevalence respectively, with a positive association with HEV infection in humans and nearly identical nucleotide sequence identity with HEV strains from local wild boars [7,14,150,168]. In Hungary, the European roe deer was implicated as a reservoir species for HEV, and in The Netherlands 5\% of red deer were also found positive for antibodies to HEV [165,167,169]. White-tailed deer in Northern Mexico carried a $62.7 \%$ anti-HEV seropositivity [170]. Increasing management of deer including feeding, watering, movement of groups, and fencing for hunting purposes in Mexico offers the ability for pathogens such as HEV to transfer between groups of deer and humans readily and may serve to disseminate pathogens to animals within the United States [170]. Sharing of habitats between wild boar and deer may play a role in the ability to harbor and transmit HEV to humans. However, without additional direct evidence of transmission within the deer species, it is difficult to determine whether deer acts as incidental or natural hosts to HEV infection $[1,20,76]$.

\subsection{HEV in Ruminants}

Ruminant (cattle, sheep and goat) strains of HEV have yet to be uncovered; however, multiple studies of anti-HEV seroprevalence indicated the possibility of their existence [7,165]. In Egypt, 11\% of cows, $14 \%$ of buffalo, $4.4 \%$ of sheep, and $9.4 \%$ of goats were tested positive for HEV antibodies [171]. Approximately $4.4-6.9 \%$ of cows and $0 \%$ of goats in India, $1.4 \%$ of cows and $0 \%$ of sheep and goats in Brazil were reportedly tested positive for anti-HEV antibodies [172,173]. Reports of anti-HEV seropositivity from China varied drastically from 6-93\% of cattle and 10-12\% of sheep [174-177]. A short sequence (189 bp) of a Genotype 4 HEV has been reportedly identified in bovid species, although independent confirmation of this unsubstantiated report is still lacking $[1,7,76]$.

Despite the abundant serological evidence for an HEV-related agent in ruminants, definitive genetic identification of $\mathrm{HEV}$ from ruminants is still lacking. It is possible that the strain carried by ruminants is very divergent genetically from the known HEV strains thus leading to failure to genetically identify the virus based upon current techniques. The serological data from ruminants is based upon cross-reaction of 
the ruminant serum samples with known HEV proteins such as ORF2 [7,165,171,172]. The validity of such serological data has been questioned due to the fact that the assays may not be specific, they do not identify the actual virus, and they may allow cross-reactivity with non-viral proteins that share a certain level of sequence homology. Research in this area must continue to better address these concerns and confirm the source of anti-HEV seropositivity in ruminants. Given the wide use of cattle, sheep, and goats in the human food chain, the genetic identification of these ruminant strains of HEV would be of a potential public health concern.

\subsection{HEV in Rats}

The rat strain of HEV was identified in wild Norway rats from Hamburg, Germany with 59.9\% and 49.9\% nucleotide sequence identity with known human and avian HEV strains, respectively [18]. Rats in the United States, Germany, Indonesia, China, and Japan are also tested seropositive for HEV antibodies in several studies with variable prevalence [18,178-181]. Overall, 44\% of rats in Louisiana, $77 \%$ in Maryland, $90 \%$ in Hawaii, 59.7\% of rats of the genus Rattus from across the United States, $32 \%$ of Norway rats in Japan, and $13 \%$ of black rats in Japan were tested positive for antibodies to HEV [178,179,182,183]. Most recently in China, 23.3\% of rats were positive for anti-HEV IgG with the highest prevalence of $45.3 \%$ from rats caught at garbage dump sites [180]. In Indonesia, 18.1\% of rats were tested positive for anti-HEV antibodies and $14.7 \%$ positive for HEV RNA [181]. Recently, Genotype 3 rat HEV strains have been genetically detected from wild rats in the United States, suggesting the potential for zoonotic transmission and the genetic variability of rat HEV [1,182]. Further studies are warranted to independently confirm the existence of Genotype 3 HEV in rats, especially since, under experimental conditions, laboratory rats are not susceptible to experimental infection by Genotype $3 \mathrm{HEV}$ [184].

\subsection{HEV in Rabbits}

Rabbits may serve as reservoir hosts for HEV transmission to humans given the genetic identification of zoonotic Genotype 3 strains of HEV from rabbits in China, the United States, and France [17,153,174,185]. Rabbits are susceptible to experimental infection by Genotype 4 human HEV, and the infected rabbits developed viremia, seroconversion to anti-HEV, and fecal virus shedding [153,185]. The rabbit HEV is genetically and antigenically closely related to other mammalian HEV. The capsid protein of the Genotype 3 rabbit strain of HEV was capable of cross-reacting with antibodies from other strains of HEV including rat, swine, human, and chicken $[1,185,186]$. The prevalence of HEV antibodies in farmed rabbits is reportedly $57 \%$ in the Gansu province in China, $54.6 \%$ in Beijing, China, and $36.5 \%$ in two rabbit farms in Virginia, USA, while HEV RNA has been identified in 7.5\%, 7.0\%, 16.5\%, and 15.3\% of the rabbits, respectively [17,153,174]. In France, HEV RNA was also identified from $7.0 \%$ of farmed rabbits, while $23.0 \%$ of wild rabbits were also positive for HEV RNA [185]. It appears that rabbits could be an important reservoir for HEV infection in humans, and in-depth studies of its ability to infect across species barriers and associated zoonotic risks in the future are needed. 


\subsection{HEV in Other Species}

Other known animal strains of HEV genetically identified thus far include mongoose, ferret, bat, and fish $[1,23,25,26,187,188]$. Wild mongoose in Okinawa, Japan carried Genotype 3 HEV strains and the prevalence of anti-HEV seropositivity varied from $8 \%$ to $21 \%[187,188]$. In The Netherlands, ferrets carried a strain of HEV that shared a $72.3 \%$ nucleotide sequence identity with that of the rat HEV [23]. The cutthroat trout in the United States also carried a unique strain of HEV with only 13\% to $27 \%$ sequence identity with known mammalian and avian HEV strains [26]. The zoonotic potentials of these novel animal strains of HEV are not altogether understood, but the ever-expanding host range and high levels of anti-HEV seropositivity among mammalian species suggests transmission is common and thus may pose a potential public health concern.

\section{Animal Handling and Zoonotic Transmission}

Contact exposure to infected animals leads to an elevated risk for HEV transmission in humans. Swine veterinarians in the United States were shown to have a 27\% seropositivity to Genotype 3 swine HEV in comparison to $16 \%$ of the normal blood donors [189]. Individuals from states in which swine production plays a key role were more likely to be seropositive to HEV than other non-major swine states [189]. Incidents such as needle sticks while working with swine were found to be1.9 times more likely positive for HEV antibodies in swine veterinarians [189]. Pig handlers such as veterinarians, breeders, and farmers in China, Thailand, The Netherlands, Sweden, Moldova, and the United States were also more likely seropositive to swine HEV [103,108,190-192]. In Sweden, 13\% of pig breeders were positive for antibodies to HEV [190]. In The Netherlands, $11 \%$ of swine veterinarians were positive in comparison to $6 \%$ of non-swine veterinarians and $2 \%$ of the general population [108]. In North Carolina, swine handlers carried a 4.5 times higher rate of seropositivity in comparison to non-swine workers [191]. In Moldova, $51 \%$ of swine farmers were positive in comparison to $25 \%$ of non-swine occupations [103]. Taken together, swine are a major reservoir for HEV and occupational contact with infected swine is a risk factor for zoonotic HEV transmission in humans.

Contact with swine is the most widely recognized route for occupational exposure to HEV; however, the multitude of novel strains of HEV in wildlife and other domestic animal species suggest additional mechanisms of transmission. For example, field workers at the Iowa Department of Natural Resources who work with a variety of wildlife species had a higher prevalence for HEV antibodies in comparison to normal blood donors [193]. While exposure to HEV, identified by the presence of anti-HEV antibodies in these populations does not in itself indicate a disease, it does identify a route of transmission and exposure that should be further assessed and acknowledged as a preventive measure against this important disease. Examination of these additional mechanisms is vital to understanding the full-spectrum of public health risk associated with HEV infection.

\section{Conclusions}

The zoonotic risk of HEV is well established; however, the ever-expanding host range and identification of new animal reservoir species poses a significant public health concern. Seroprevalence in human and other animal species varies drastically between studies and countries with no clear understanding of 
the overall problem, and this is largely due to the lack of an established FDA-approved serological diagnostic assay. Numerous animal species were tested seropositive for IgG anti-HEV, although HEV was not genetically identified from all seropositive animal species. Detection of HEV in sewage, water sources, coastal and surface waters, and produce poses environmental safety concerns even in industrialized countries where waterborne origins of human hepatitis E cases were previously considered rare. Foodborne cases of hepatitis E in humans are increasingly common and likely underestimated in the medical community. Sporadic and cluster cases of hepatitis E occur after consumption of undercooked or raw animal meats. Prevention of foodborne HEV transmission relies on avoiding consumption of undercooked animal meats especially when immunocompromised, following good hygiene practices, and being aware of increased risks when traveling to endemic or hyperendemic regions of the world. Despite the clear risk, prevention strategies are currently minimally implemented. A vaccine against HEV has recently become available in China but not in other countries. Surveillance, vaccination, de-contamination of sewage and water sources, and public education will help prevent current and future endemics or epidemics lowering the human burden. The development of a vaccine against the zoonotic swine HEV would reduce foodborne and swine contact cases in humans as well as diminish the spread of the virus between animal species. Control of animal waste, run-off, and decontaminated sewage is key to limiting the spread of HEV to coastal and surface waters and in turn reducing concomitant contamination of shellfish.

\section{Acknowledgments}

The authors' research on HEV is supported by grants from the National Institutes of Health (R01AI074667, and R01AI050611). Danielle M. Yugo is supported by a training grant from the National Institutes of Health (T32OD010430-06). This review article encompasses a comprehensive literature review with a focus on food and environmental safety and zoonotic risk of HEV. Due to the narrow scope of the topic and space constraints, many important articles regarding HEV may be unintentionally excluded from this review. We have attempted to include the most recent publications including review articles in order to provide the reader with up to date and comprehensive information on the topic.

\section{Conflicts of Interest}

The authors declare no conflicts of interest.

\section{References}

1. Meng, X.J. Zoonotic and foodborne transmission of hepatitis E virus. Semin. Liver. Dis. 2013, 33, 41-49.

2. Emerson, S.; Purcell, R. Hepatitis E. Pediatr. Infect. Dis. J. 2007, 26, 1147-1148.

3. Sanford, B.; Dryman, B.; Huang, Y.-W.; Feagins, A.; Leroith, T.; Meng, X.J. Prior infection of pigs with a genotype 3 swine hepatitis $\mathrm{E}$ virus (HEV) protects against subsequent challenges with homologous and heterologous genotypes 3 and 4 human HEV. Virus Res. 2011, 159, 17-22.

4. Emerson, S.; Purcell, R. Hepatitis E virus. Rev. Med. Virol. 2003, 13, 145-154. 
5. Meng, X.J. Hepatitis E virus: Animal reservoirs and zoonotic risk. Vet. Microbiol. 2010, 140, $256-265$.

6. Dalton, H.; Bendall, R.; Ijaz, S.; Banks, M. Hepatitis E: An emerging infection in developed countries. Lancet Infect. Dis. 2008, 8, 698-709.

7. Meng, X.J. From barnyard to food table: The omnipresence of hepatitis E virus and risk for zoonotic infection and food safety. Virus Res. 2011, 161, 23-30.

8. Purcell, R.; Emerson, S. Hepatitis E: An emerging awareness of an old disease. J. Hepatol. 2008, 48, 494-503.

9. Péron, J.; Dalton, H.; Izopet, J.; Kamar, N. Acute autochthonous hepatitis E in western patients with underlying chronic liver disease: A role for ribavirin? J. Hepatol. 2011, 54, 1323-1324.

10. Kumar, S.; Subhadra, S.; Singh, B.; Panda, B. Hepatitis E virus: The current scenario. Int. J. Infect. Dis. 2013, 17, e228-e233.

11. Colson, P.; Borentain, P.; Queyriaux, B.; Kaba, M.; Moal, V.; Gallian, P.; Heyries, L.; Raoult, D.; Gerolami, R. Pig liver sausage as a source of hepatitis E virus transmission to humans. J. Infect. Dis. 2010, 202, 825-834.

12. Tei, S.; Kitajima, N.; Takahashi, K.; Mishiro, S. Zoonotic transmission of hepatitis E virus from deer to human beings. Lancet 2003, 362, 371-373.

13. Yazaki, Y.; Mizuo, H.; Takahashi, M.; Nishizawa, T.; Sasaki, N.; Gotanda, Y.; Okamoto, H. Sporadic acute or fulminant hepatitis E in Hokkaido, Japan, may be food-borne, as suggested by the presence of hepatitis E virus in pig liver as food. J. Gen. Virol. 2003, 84, 2351-2357.

14. Takahashi, K.; Kitajima, N.; Abe, N.; Mishiro, S. Complete or near-complete nucleotide sequences of hepatitis E virus genome recovered from a wild boar, a deer, and four patients who ate the deer. Virology 2004, 330, 501-505.

15. De Deus, N.; Peralta, B.; Pina, S.; Allepuz, A.; Mateu, E.; Vidal, D.; Ruiz-Fons, F.; Martın, M.; Gortazar, C.; Segales, J. Epidemiological study of hepatitis E virus infection in European wild boars (Sus scrofa) in Spain. Vet. Microbiol. 2008, 129, 163-170.

16. Zhao, C.; Ma, Z.; Harrison, T.J.; Feng, R.; Zhang, C.; Qiao, Z.; Fan, J.; Ma, H.; Li, M.; Song, A.; et al. A novel genotype of hepatitis E virus prevalent among farmed rabbits in China. J. Med. Virol. 2009, 81, 1371-1379.

17. Cossaboom, C.; Córdoba, L.; Dryman, B.; Meng, X.J. Hepatitis E virus in rabbits, Virginia, USA. Emerg. Infect. Dis. 2012, 17, 2047-2049.

18. Johne, R.; Heckel, G.; Plenge-Bönig, A.; Kindler, E.; Maresch, C.; Reetz, J.; Schielke, A.; Ulrich, R. Novel hepatitis E virus genotype in Norway rats, Germany. Emerg. Infect. Dis. 2011, 16, 1452-1455.

19. Nidaira, M.; Takahashi, K.; Ogura, G.; Taira, K.; Okano, S.; Kudaka, J.; Itokazu, K.; Mishiro, S.; Nakamura, M. Detection and phylogenetic analysis of hepatitis E viruses from mongooses in Okinawa, Japan. J. Vet. Med. Sci. 2012, 74, 1665-1668.

20. Pavio, N.; Meng, X.J.; Renou, C. Zoonotic hepatitis E: Animal reservoirs and emerging risks. Vet. Res. 2010, 41, 46, doi:10.1051/vetres/2010018. 
21. Marek, A.; Bilic, I.; Prokofieva, I.; Hess, M. Phylogenetic analysis of avian hepatitis E virus samples from European and Australian chicken flocks supports the existence of a different genus within the Hepeviridae comprising at least three different genotypes. Vet. Microbiol. 2010, 145, 54-61.

22. Kwon, H.; Sung, H.; Meng, X.J. Serological prevalence, genetic identification, and characterization of the first strains of avian hepatitis E virus from chickens in Korea. Virus Genes 2012, 45, 237-245.

23. Raj, V.; Smits, S.; Pas, S.; Provacia, L.; Moorman-Roest, H.; Osterhaus, A.; Haagmans, B. Novel hepatitis E virus in ferrets, The Netherlands. Emerg. Infect. Dis. 2012, 18, 1369-1370.

24. Takahashi, M.; Nishizawa, T.; Sato, H.; Sato, Y.; Jirintai, S.; Nagashima, S.; Okamoto, H. Analysis of the full-length genome of a hepatitis E virus isolate obtained from a wild boar in Japan that is classifiable into a novel genotype. J. Gen. Virol. 2011, 92, 902-908.

25. Drexler, J.F.; Seelen, A.; Corman, V.M.; Fumie Tateno, A.; Cottontail, V.; Melim Zerbinati, R.; Gloza-Rausch, F.; Klose, S.M.; Adu-Sarkodie, Y.; Oppong, S.K.; et al. Bats worldwide carry hepatitis $\mathrm{E}$ virus-related viruses that form a putative novel genus within the family hepeviridae. J. Virol. 2012, 86, 9134-9147.

26. Batts, W.; Yun, S.; Hedrick, R.; Winton, J. A novel member of the family hepeviridae from cutthroat trout (Oncorhynchus clarkii). Virus Res. 2011, 158, 116-123.

27. Emerson, S.; Nguyen, H.; Torian, U.; Mather, K.; Firth, A. An essential RNA element resides in a central region of hepatitis E virus ORF2. J. Gen. Virol. 2013, 94, 1468-1476.

28. Koonin, E.; Gorbalenya, A.; Purdy, M.; Rozanov, M.; Reyes, G.; Bradley, D. Computer-assisted assignment of functional domains in the nonstructural polyprotein of hepatitis $\mathrm{E}$ virus: Delineation of an additional group of positive-strand RNA plant and animal viruses. Proc. Natl. Acad. Sci. USA 1992, 89, 8259-8263.

29. Pudupakam, R.; Huang, Y.; Opriessnig, T.; Halbur, P.; Pierson, F.; Meng, X.J. Deletions of the hypervariable region (HVR) in open reading frame 1 of hepatitis $\mathrm{E}$ virus do not abolish virus infectivity: Evidence for attenuation of HVR deletion mutants in vivo. J. Virol. 2009, 83, 384-395.

30. Surjit, M.; Jameel, S.; Lal, S. Cytoplasmic localization of the ORF2 protein of hepatitis E virus is dependent on its ability to undergo retrotranslocation from the endoplasmic reticulum. J. Virol. 2007, 81, 3339-3345.

31. Graff, J.; Zhou, Y.H.; Torian, U.; Nguyen, H.; St Claire, M.; Yu, C.; Purcell, R.; Emerson, S. Mutations within potential glycosylation sites in the capsid protein of hepatitis $\mathrm{E}$ virus prevent the formation of infectious virus particles. J. Virol. 2008, 82, 1185-1194.

32. Graff, J.; Nguyen, H.; Kasorndorkbua, C.; Halbur, P.; St Claire, M.; Purcell, R.; Emerson, S. In vitro and in vivo mutational analysis of the 3'-terminal regions of hepatitis $\mathrm{E}$ virus genomes and replicons. J. Virol. 2005, 79, 1017-1026.

33. Graff, J.; Nguyen, H.; Yu, C.; Elkins, W.; St Claire, M.; Purcell, R.; Emerson, S. The open reading frame 3 gene of hepatitis $\mathrm{E}$ virus contains a cis-reactive element and encodes a protein required for infection of macaques. J. Virol. 2005, 79, 6680-6689.

34. Haqshenas, G.; Shivaprasad, H.; Woolcock, P.; Read, D.; Meng, X.J. Genetic identification and characterization of a novel virus related to human hepatitis $\mathrm{E}$ virus from chickens with hepatitis-splenomegaly syndrome in the United States. J. Gen. Virol. 2001, 82, 2449-2462. 
35. Huang, F.; Sun, Z.; Emerson, S.; Purcell, R.; Shivaprasad, H.; Pierson, F.; Toth, T.; Meng, X.J. Determination and analysis of the complete genomic sequence of avian hepatitis E virus (avian HEV) and attempts to infect rhesus monkeys with avian HEV. J. Gen. Virol. 2004, 85, $1609-1618$.

36. Huang, F.F.; Haqshenas, G.; Shivaprasad, H.L.; Guenette, D.K.; Woolcock, P.R.; Larsen, C.T.; Pierson, F.W.; Elvinger, F.; Toth, T.E.; Meng, X.J. Heterogeneity and seroprevalence of a newly identified avian hepatitis E virus from chickens in the United States. J. Clin. Microbiol. 2002, 40, 4197-4202.

37. Bouquet, J.; Cherel, P.; Pavio, N. Genetic characterization and codon usage bias of full-length hepatitis $\mathrm{E}$ virus sequences shed new lights on genotypic distribution, host restriction and genome evolution. Infect. Genet. Evol. 2012, 12, 1842-1853.

38. Cao, D.; Meng, X.J. Molecular biology and replication of hepatitis E virus. Emerg. Microb. Infect. 2012, 1, e17, doi:10.1038/emi.2012.7.

39. Graff, J.; Torian, U.; Nguyen, H.; Emerson, S. A bicistronic subgenomic mRNA encodes both the ORF2 and ORF3 proteins of hepatitis E virus. J. Virol. 2006, 80, 5919-5926.

40. Meng, X.J.; Halbur, P.; Shapiro, M.; Govindarajan, S.; Bruna, J.; Mushahwar, I.; Purcell, R.; Emerson, S. Genetic and experimental evidence for cross-species infection by swine hepatitis $\mathrm{E}$ virus. J. Virol. 1998, 72, 9714-9721.

41. Purcell, R.E., Emerson, S.U., Hepatitis E Virus. In Fields Virology, 4th ed.; Fields, B.N., Knipe, D.M., Eds. Lippincott Williams \& Wilkins: Philadelphia, PA, USA, 2001; pp 3051-3061.

42. Kamar, N.; Selves, J.; Mansuy, J.M.; Ouezzani, L.; Péron, J.M.; Guitard, J.; Cointault, O.; Esposito, L.; Abravanel, F.; Danjoux, M.; et al. Hepatitis E virus and chronic hepatitis in organ-transplant recipients. New Engl. J. Med. 2008, 358, 811-817.

43. Le Coutre, P.; Meisel, H.; Hofmann, J.; Röcken, C.; Vuong, G.; Neuburger, S.; Hemmati, P.; Dörken, B.; Arnold, R. Reactivation of hepatitis E infection in a patient with acute lymphoblastic leukaemia after allogeneic stem cell transplantation. Gut 2009, 58, 699-702.

44. Ollier, L.; Bigaillon, C.; Tieulie, N.; Tesse, S.; Heudier, P.; Sanderson, F.; Giordanengo, V.; Nicand, E.; Fuzibet, J.G. Hepatitis E initially serologically silent with prolonged evolution in a patient treated for a lymphoma. Presse Med. 2009, 38, 1700-1704.

45. Dalton, H.R.; Bendall, R.P.; Keane, F.E.; Tedder, R.S.; Ijaz, S. Persistent carriage of hepatitis E virus in patients with HIV infection. N. Engl. J. Med. 2009, 361, 1025-1027.

46. Haagsma, E.; van den Berg, A.; Porte, R.; Benne, C.; Vennema, H.; Reimerink, J.; Koopmans, M. Chronic hepatitis E virus infection in liver transplant recipients. Liver Transplant. 2008, 14, 547-553.

47. Teshale, E.H.; Hu, D.J.; Holmberg, S.D. The two faces of hepatitis E virus. Clin. Infect. Dis. 2010, 51, 328-334.

48. Takahashi, M.; Okamoto, H. Features of hepatitis E virus infection in humans and animals in Japan. Hepatol. Res. 2013, doi:10.1111/hepr.12175.

49. Mansuy, J.M.; Abravanel, F.; Miedouge, M.; Mengelle, C.; Merviel, C.; Dubois, M.; Kamar, N.; Rostaing, L.; Alric, L.; Moreau, J.; et al. Acute hepatitis E in south-west France over a 5-year period. J. Clin. Virol. 2009, 44, 74-77. 
50. Dalton, H.R.; Bendall, R.P.; Rashid, M.; Ellis, V.; Ali, R.; Ramnarace, R.; Stableforth, W.; Headdon, W.; Abbott, R.; McLaughlin, C.; et al. Host risk factors and autochthonous hepatitis E infection. Eur. J. Gastroenterol. Hepatol. 2011, 23, 1200-1205.

51. Brost, S.; Wenzel, J.J.; Ganten, T.M.; Filser, M.; Flechtenmacher, C.; Boehm, S.; Astani, A.; Jilg, W.; Zeier, M.; Schnitzler, P. Sporadic cases of acute autochthonous hepatitis E virus infection in Southwest Germany. J. Clin. Virol. 2010, 47, 89-92.

52. Hussaini, S.; Skidmore, S.; Richardson, P.; Sherratt, L.; Cooper, B.; O’Grady, J. Severe hepatitis E infection during pregnancy. J. Viral. Hepatitis 1997, 4, 51-54.

53. Khuroo, M.; Kamili, S.; Jameel, S. Vertical transmission of hepatitis E virus. Lancet 1995, 345, 1025-1026.

54. Renou, C.; Pariente, A.; Nicand, E.; Pavio, N. Pathogenesis of hepatitis E in pregnancy. Liver Int. 2008, 28, 1465.

55. Mushahwar, I. Hepatitis E virus: Molecular virology, clinical features, diagnosis, transmission, epidemiology, and prevention. J. Med. Virol. 2008, 80, 646-658.

56. Kumar, A.; Beniwal, M.; Kar, P.; Sharma, J.; Murthy, N. Hepatitis E in pregnancy. Int. J. Gynecol. Obstet. 2004, 85, 240-244.

57. Chibber, R.; Usmani, M.; Al-Sibai, M. Should HEV infected mothers breast feed? Arch. Gynecol. Obstet. 2004, 270, 15-20.

58. Matsubayashi, K.; Kang, J.H.; Sakata, H.; Takahashi, K.; Shindo, M.; Kato, M.; Sato, S.; Kato, T.; Nishimori, H.; Tsuji, K.; et al. A case of transfusion-transmitted hepatitis E caused by blood from a donor infected with hepatitis E virus via zoonotic food-borne route. Transfusion 2008, 48, $1368-1375$.

59. Boxall, E.; Herborn, A.; Kochethu, G.; Pratt, G.; Adams, D.; Ijaz, S.; Teo, C.G. Transfusion-transmitted hepatitis E in a "nonhyperendemic" country. Transfus. Med. 2006, 16, 79-83.

60. Arankalle, V.; Chobe, L. Retrospective analysis of blood transfusion recipients: Evidence for post-transfusion hepatitis E. Vox. Sang. 2000, 79, 72-74.

61. Meng, X.J.; Purcell, R.; Halbur, P.; Lehman, J.; Webb, D.; Tsareva, T.; Haynes, J.; Thacker, B.; Emerson, S. A novel virus in swine is closely related to the human hepatitis E virus. Proc. Natl. Acad. Sci. USA. 1997, 94, 9860-9865.

62. Halbur, P.; Kasorndorkbua, C.; Gilbert, C.; Guenette, D.; Potters, M.; Purcell, R.; Emerson, S.; Toth, T.; Meng, X.J. Comparative pathogenesis of infection of pigs with hepatitis E viruses recovered from a pig and a human. J. Clin. Microbiol. 2001, 39, 918-923.

63. Leblanc, D.; Ward, P.; Gagné, M.J.; Poitras, E.; Müller, P.; Trottier, Y.L.; Simard, C.; Houde, A. Presence of hepatitis E virus in a naturally infected swine herd from nursery to slaughter. Int. J. Food Microbiol. 2007, 117, 160-166.

64. De Deus, N.; Casas, M.; Peralta, B.; Nofrarías, M.; Pina, S.; Martín, M.; Segalés, J. Hepatitis E virus infection dynamics and organic distribution in naturally infected pigs in a farrow-to-finish farm. Vet. Microbiol. 2008, 132, 19-28.

65. McCreary, C.; Martelli, F.; Grierson, S.; Ostanello, F.; Nevel, A.; Banks, M. Excretion of hepatitis $\mathrm{E}$ virus by pigs of different ages and its presence in slurry stores in the United Kingdom. Vet. Rec. 2008, 163, 261-265. 
66. Nakai, I.; Kato, K.; Miyazaki, A.; Yoshii, M.; Li, T.C.; Takeda, N.; Tsunemitsu, H.; Ikeda, H. Different fecal shedding patterns of two common strains of hepatitis E virus at three Japanese swine farms. Am. J. Trop. Med. Hyg. 2006, 75, 1171-1177.

67. Albinana-Gimenez, N.; Clemente-Casares, P.; Bofill-Mas, S.; Hundesa, A.; Ribas, F.; Girones, R. Distribution of human polyomaviruses, adenoviruses, and hepatitis $\mathrm{E}$ virus in the environment and in a drinking-water treatment plant. Environ. Sci. Technol. 2006, 40, 7416-7422.

68. Feagins, A.; Opriessnig, T.; Huang, Y.; Halbur, P.; Meng, X.J. Cross-species infection of specific-pathogen-free pigs by a genotype 4 strain of human hepatitis E virus. J. Med. Virol. 2008, 80, 1379-1386.

69. Kasorndorkbua, C.; Guenette, D.K.; Huang, F.F.; Thomas, P.J.; Meng, X.J.; Halbur, P.G. Routes of transmission of swine hepatitis E virus in pigs. J. Clin. Microbiol. 2004, 42, 5047-5052.

70. Bouwknegt, M.; Frankena, K.; Rutjes, S.A.; Wellenberg, G.J.; de Roda Husman, A.M.; van der Poel, W.H; de Jong, M.C. Estimation of hepatitis E virus transmission among pigs due to contact-exposure. Vet. Res. 2008, 39, 40, doi:10.1051/vetres:2008017.

71. Sun, Z.; Larsen, C.; Dunlop, A.; Huang, F.; Pierson, F.; Toth, T.; Meng, X.J. Genetic identification of avian hepatitis E virus (HEV) from healthy chicken flocks and characterization of the capsid gene of 14 avian HEV isolates from chickens with hepatitis-splenomegaly syndrome in different geographical regions of the United States. J. Gen. Virol. 2004, 85, 693-700.

72. Peralta, B.; Biarnés, M.; Ordóñez, G.; Porta, R.N.; Martín, M.; Mateu, E.; Pina, S.; Meng, X.J. Evidence of widespread infection of avian hepatitis E virus (avian HEV) in chickens from Spain. Vet. Microbiol. 2009, 137, 31-36.

73. Meng, X.J.; Shivaprasad, H.L.; Payne, C. Hepatitis E Virus Infections. In Diseases of Poultry, 12th ed.; Saif, Y.M., Fadly, A.M., Glisson, J.R. et al, Eds; Blackwell Publishing Press: Ames, IA, USA, 2008; pp. 443-452.

74. Billam, P.; Huang, F.; Sun, Z.; Pierson, F.; Duncan, R.; Elvinger, F.; Guenette, D.; Toth, T.; Meng, X.J. Systematic pathogenesis and replication of avian hepatitis $E$ virus in specific-pathogen-free adult chickens. J. Virol. 2005, 79, 3429-3437.

75. Teo, C.G. Hepatitis E. In CDC Health Information for International Travel 2010; Brunette, G.W., Kozarsky, P., Magill, A.J., Shliml, D.R., Whatley, A.D., Eds; Mosby: St. Louis, MO, USA, 2009; pp. 335-337.

76. Teo, C.G. Much meat, much malady: Changing perceptions of the epidemiology of hepatitis E. Clin. Microbiol. Infect. 2010, 16, 24-32.

77. Zuckerman, J. Hepatitis E and the traveler. Travel Med. Infect. Dis. 2003, 1, 73-76.

78. Buti, M.; Dominguez, A.; Plans, P.; Jardi, R.; Schaper, M.; Espunes, J.; Cardenosa, N.; Rodriguez-Frias, F.; Esteban, R.; Plasencia, A.; et al. Community-based seroepidemiological survey of hepatitis E virus infection in Catalonia, Spain. Clin. Vaccine Immunol. 2006, 13, 13281332.

79. Ijaz, S.; Arnold, E.; Banks, M.; Bendall, R.P.; Cramp, M.E.; Cunningham, R.; Dalton, H.R.; Harrison, T.J.; Hill, S.F.; Macfarlane, L.; et al. Non-travel-associated hepatitis E in England and Wales: Demographic, clinical, and molecular epidemiological characteristics. J. Infect. Dis. 2005, 192, 1166-1172. 
80. Fukuda, S.; Ishikawa, M.; Ochiai, N.; Suzuki, Y.; Sunaga, J.; Shinohara, N.; Nozawa, K.; Tsuda, F.; Takahashi, M.; Okamoto, H. Unchanged high prevalence of antibodies to hepatitis E virus (HEV) and HEV RNA among blood donors with an elevated alanine aminotransferase level in Japan during 1991-2006. Arch. Virol. 2007, 152, 1623-1635.

81. Mansuy, J.M.; Bendall, R.; Legrand-Abravanel, F.; Saune, K.; Miedouge, M.; Ellis, V.; Rech, H.; Destruel, F.; Kamar, N.; Dalton, H.R.; et al. Hepatitis E virus antibodies in blood donors, France. Emerg. Infect. Dis. 2011, 17, 2309-2312.

82. Christensen, P.B.; Engle, R.E.; Hjort, C.; Homburg, K.M.; Vach, W.; Georgsen, J.; Purcell, R.H. Time trend of the prevalence of hepatitis E antibodies among farmers and blood donors: A potential zoonosis in Denmark. Clin. Infect. Dis. 2008, 47, 1026-1031.

83. Purdy, M.A.; Khudyakov, Y.E. Evolutionary history and population dynamics of hepatitis E virus. PIOS One 2010, 5, e14376, doi:10.1371/journal.pone.0014376.

84. Takahashi, M.; Nishizawa, T.; Gotanda, Y.; Tsuda, F.; Komatsu, F.; Kawabata, T.; Hasegawa, K.; Altankhuu, M.; Chimedregzen, U.; Narantuya, L.; et al. High prevalence of antibodies to hepatitis $\mathrm{A}$ and $\mathrm{E}$ viruses and viremia of hepatitis B, C, and D viruses among apparently healthy populations in Mongolia. Clin. Diagn. Lab. Immun. 2004, 11, 392-398.

85. Li, R.C.; Ge, S.X.; Li, Y.P.; Zheng, Y.J.; Nong, Y.; Guo, Q.S.; Zhang, J.; Ng, M.H.; Xia, N.S. Seroprevalence of hepatitis E virus infection, rural southern People's Republic of China. Emerg. Infect. Dis. 2006, 12, 1682-1688.

86. Wong, K.H.; Liu, Y.M.; Ng, P.S.; Young, B.W.; Lee, S.S. Epidemiology of hepatitis A and hepatitis E infection and their determinants in adult Chinese community in Hong Kong. J. Med. Virol. 2004, 72, 538-544.

87. Arankalle, V.A.; Chadha, M.S.; Chitambar, S.D.; Walimbe, A.M.; Chobe, L.P.; Gandhe, S.S. Changing epidemiology of hepatitis A and hepatitis E in urban and rural India (1982-98). J. Viral Hepat. 2001, 8, 293-303.

88. Aggarwal, R.; Naik, S. Epidemiology of hepatitis E: Current status. J. Gastroenterol. Hepatol. 2009, 24, 1484-1493.

89. Fu, H.; Li, L.; Zhu, Y.; Wang, L.; Geng, J.; Chang, Y.; Xue, C.; Du, G.; Li, Y.; Zhuang, H. Hepatitis E virus infection among animals and humans in Xinjiang, China: Possibility of swine to human transmission of sporadic hepatitis E in an endemic area. Am. J. Trop. Med. Hyg. 2010, 82, 961-966.

90. Toole, M.; Claridge, F.; Anderson, D.; Zhuang, H.; Morgan, C.; Otto, B.; Stewart, T. Hepatitis E virus infection as a marker for contaminated community drinking water sources in Tibetan villages. Am. J. Trop. Med. Hyg. 2006, 74, 250-254.

91. Sedyaningsih-Mamahit, E.; Larasati, R.; Laras, K.; Sidemen, A.; Sukri, N.; Sabaruddin, N.; Didi, S.; Saragih, J.; Myint, K.; Endy, T.; et al. First documented outbreak of hepatitis E virus transmission in Java, Indonesia. T. Roy. Soc. Trop. Med. H. 2002, 96, 398-404.

92. Corwin, A.; Tien, N.; Bounlu, K.; Winarno, J.; Putri, M.; Laras, K.; Larasati, R.; Sukri, N.; Endy, T.; Sulaiman, H.; Hyams, K. The unique riverine ecology of hepatitis E virus transmission in South-East Asia. Trans. R. Soc. Trop. Med. Hyg. 1999, 93, 255-260. 
93. Ceylan, A.; Ertem, M.; Ilcin, E.; Ozekinci, T. A special risk group for hepatitis E infection: Turkish agricultural workers who use untreated waste water for irrigation. Epidemiol. Infect. 2003, 131, 753-756.

94. Bile, K.; Isse, A.; Mohamud, O.; Allebeck, P.; Nilsson, L.; Norder, H.; Mushahwar, I.; Magnius, L. Contrasting roles of rivers and wells as sources of drinking water on attack and fatality rates in a hepatitis E epidemic in Somalia. Am. J. Trop. Med. Hyg. 1994, 51, 466-474.

95. Clemente-Casares, P.; Pina, S.; Buti, M.; Jardi, R.; MartIn, M.; Bofill-Mas, Girones, R. Hepatitis E virus epidemiology in industrialized countries. Emerg. Infect. Dis. 2003, 9, 448-454.

96. Ippagunta, S.K.; Naik, S.; Sharma, B.; Aggarwal, R. Presence of hepatitis E virus in sewage in Northern India: Frequency and seasonal pattern. Med. Virol. 2007, 79, 1827-1831.

97. Jothikumar, N.; Aparna, K.; Kamatchiammal, S.; Paulmurugan, R.; Saravanadevi, S.; Khanna, P. Detection of hepatitis $\mathrm{E}$ virus in raw and treated wastewater with the polymerase chain reaction. Appl. Environ. Microbiol. 1993, 59, 2558-2562.

98. Pina, S.; Buti, M.; Cotrina, M.; Piella, J.; Girones, R. HEV identified in serum from humans with acute hepatitis and in sewage of animal origin in Spain. J. Hepatol. 2000, 33, 826-833.

99. Vaidya, S.; Tilekar, B.; Walimbe, A.; Arankalle, V. Increased risk of hepatitis E in sewage workers from India. J. Occup. Environ. Med. 2003, 45, 1167-1170.

100. Rutjes, S.; Lodder, W.; Lodder-Verschoor, F.; van den Berg, H.; Vennema, H.; Duizer, E.; Koopmans, M.; de Roda Husman, A. Sources of hepatitis E virus genotype 3 in The Netherlands. Emerg. Infect. Dis. 2009, 15, 381-387.

101. Borgen, K.; Herremans, T.; Duizer, E.; Vennema, H.; Rutjes, S.; Bosman, A.; de Roda Husman, A.M.; Koopmans, M. Non-travel related Hepatitis E virus genotype 3 infections in The Netherlands; A case series 2004-2006. BMC Infect. Dis. 2008, 8, doi:10.1186/1471-2334-8-61.

102. El-Esnawy, N.A. Examination for hepatitis E virus in wastewater treatment plants and workers by nested RT-PCR and ELISA. J. Egypt. Public Health Assoc. 2000, 75, 219-231.

103. Bouwknegt, M.; Engel, B.; Herremans, M.; Widdowson, M.; Worm, H.; Koopmans, M.; Frankena, K.; de Roda Husman, A.; de Jong, M.; van der Poel, W. Bayesian estimation of hepatitis $\mathrm{E}$ virus seroprevalence for populations with different exposure levels to swine in The Netherlands. Epidemiol. Infect. 2008, 136, 567-576.

104. Galiana, C.; Fernandez-Barredo, S.; Garcia, A.; Gomez, M.T.; Perez-Gracia, M.T. Occupational exposure to hepatitis E virus (HEV) in swine workers. Am. J. Trop. Med. Hyg. 2008, 78, 1012-1015.

105. Bendall, R.; Ellis, V.; Ijaz, S.; Ali, R.; Dalton, H. A comparison of two commercially available anti-HEV IgG kits and a re-evaluation of anti-HEV IgG seroprevalence data in developed countries. J. Med. Virol. 2010, 82, 799-805.

106. Baylis, S.A.; Blumel, J.; Mizusawa, S.; Matsubayashi, K.; Sakata, H.; Okada, Y.; Nubling, C.M.; Hanschmann, K.M.; the HEV Collaborative Study Group. World Health Organization International Standard to harmonize assays for detection of hepatitis E virus RNA. Emerg. Infect. Dis. 2013, 19, 729-735.

107. Vulcano, A.; Angelucci, M.; Candelori, E.; Martini, V.; Patti, A.M.; Mancini, C.; Santi, A.L.; Calvani, A.; Casagni, L.; Lamberti, A. HEV prevalence in the general population and among workers at zoonotic risk in Latium Region. Ann. Ig. 2007, 19, 181-186. 
108. Olsen, B.; Axelsson-Olsson, D.; Thelin, A.; Weiland, O. Unexpected high prevalence of IgG-antibodies to hepatitis E virus in Swedish pig farmers and controls. Scand. J. Infect. Dis. 2006, 38, 55-58.

109. Kasorndorkbua, C.; Opriessnig, T.; Huang, F.F.; Guenette, D.K.; Thomas, P.J.; Meng, X.J.; Halbur, P.G. Infectious swine hepatitis E virus is present in pig manure storage facilities on United States farms, but evidence of water contamination is lacking. Appl. Environ. Microbiol. 2005, 71, 7831-7837.

110. Rodriguez-Lazaro, D.; Cook, N.; Ruggeri, F.M.; Sellwood, J.; Nasser, A.; Nascimento, M.S.; D’Agostino, M.; Santos, R.; Saiz, J.C.; Rzezutka, A.; et al. Virus hazards from food, water and other contaminated environments. FEMS Microbiol. Rev. 2012, 36, 786-814.

111. Jimenez-Clavero, M.A.; Escribano-Romero, E.; Mansilla, C.; Gomez, N.; Cordoba, L.; Roblas, N.; Ponz, F.; Ley, V.; Saiz, J.C. Survey of bovine enterovirus in biological and environmental samples by a highly sensitive real-time reverse transcription-PCR. Appl. Environ. Microbiol. 2005, 71, 3536-3543.

112. Brassard, J.; Gagné, M.J.; Généreux, M.; Côté, C. Detection of human food-borne and zoonotic viruses on irrigated, field-grown strawberries. Appl. Environ. Microbiol. 2012, 78, 3763-3766.

113. Ward, P.; Muller, P.; Letellier, A.; Quessy, S.; Simard, C.; Trottier, Y.L.; Houde, A.; Brassard, J. Molecular characterization of hepatitis E virus detected in swine farms in the province of Quebec. Can. J. Vet. Res. 2008, 72, 27-31.

114. Steyer, A.; Naglič, T.; Močilnik, T.; Poljšak-Prijatelj, M.; Poljak, M. Hepatitis E virus in domestic pigs and surface waters in Slovenia: Prevalence and molecular characterization of a novel genotype 3 lineage. Infect. Genet. Evol. 2011, 11, 1732-1737.

115. Tyrrel, S.F.; Quinton, J.N. Overland flow transport of pathogens from agricultural land receiving faecal wastes. J. Appl. Microbiol. 2003, 94 (Suppl. S1), 87S-93S.

116. Ziemer, C.; Bonner, J.; Cole, D.; Vinjé, J.; Constantini, V.; Goyal, S.; Gramer, M.; Mackie, R.; Meng, X.J.; Myers, G.; et al. Fate and transport of zoonotic, bacterial, viral, and parasitic pathogens during swine manure treatment, storage, and land application. J. Anim. Sci. 2010, 88 (Suppl. S13), E84-E94.

117. Lewis, H.C.; Wichmann, O.; Duizer, E. Transmission routes and risk factors for autochthonous hepatitis E virus infection in Europe: A systematic review. Epidemiol. Infect. 2010, 138, 145-166.

118. Namsai, A.; Louisirirotchanakul, S.; Wongchinda, N.; Siripanyaphinyo, U.; Virulhakul, P.; Puthavathana, P.; Myint, K.; Gannarong, M.; Ittapong, R. Surveillance of hepatitis A and E viruses contamination in shellfish in Thailand. Lett. Appl. Microbiol. 2011, 53, 608-613.

119. Emerson, S.; Arankalle, V.; Purcell, R. Thermal stability of hepatitis E virus. J. Infect. Dis. 2005, 192, 930-933.

120. Said, B.; Ijaz, S.; Kafatos, G.; Booth, L.; Thomas, H.L.; Walsh, A.; Ramsay, M.E.; Morgan, D.; the Hepatitis E Incident Investigation Team. Hepatitis E outbreak on cruise ship. Emerg. Infect. Dis. 2009, 15, 1738-1744.

121. Diez-Valcarce, M.; Kokkinos, P.; Söderberg, K.; Bouwknegt, M.; Willems, K.; de Roda-Husman, A.M.; von Bonsdorff, C.H.; Bellou, M.; Hernández, M.; Maunula, L.; et al. Occurrence of human enteric viruses in commercial mussels at retail level in three European countries. Food Environ. Virol. 2012, 4, 73-80. 
122. Crossan, C.; Baker, P.; Craft, J.; Takeuchi, Y.; Dalton, H.; Scobie, L. Hepatitis E virus genotype 3 in shellfish, United Kingdom. Emerg. Infect. Dis. 2012, 18, 2085-2087.

123. Cacopardo, B.; Russo, R.; Preiser, W.; Benanti, F.; Brancati, G.; Nunnari, A. Acute hepatitis E in Catania (eastern Sicily) 1980-1994. The role of hepatitis E virus. Infection 1997, 25, 313-316.

124. Renou, C.; Moreau, X.; Pariente, A.; Cadranel, J.F.; Maringe, E.; Morin, T.; Causse, X.; Payen, J.L.; Izopet, J.; Nicand, E.; et al. A national survey of acute hepatitis E in France. Aliment. Pharmacol. Ther. 2008, 27, 1086-1093.

125. Song, Y.J.; Jeong, H.J.; Kim, Y.J.; Lee, S.W.; Lee, J.B.; Park, S.Y.; Song, C.S.; Park, H.M.; Choi, I.S. Analysis of complete genome sequences of swine hepatitis E virus and possible risk factors for transmission of HEV to humans in Korea. J. Med. Virol. 2010, 82, 583-591.

126. Li, T.C.; Miyamura, T.; Takeda, N. Detection of hepatitis E virus RNA from the bivalve Yamato-Shijimi (Corbicula japonica) in Japan. Am. J. Trop. Med. Hyg. 2007, 76, 170-172.

127. Kamar, N.; Bendall, R.; Legrand-Abravanel, F.; Xia, N.S.; Ijaz, S.; Izopet, J.; Dalton, H.R. Hepatitis E. Lancet 2012, 379, 2477-2488.

128. Billam, P.; Pierson, F.; Li, W.; LeRoith, T.; Duncan, R.; Meng, X.J. Development and validation of a negative-strand-specific reverse transcription-PCR assay for detection of a chicken strain of hepatitis E virus: Identification of nonliver replication sites. J. Clin. Microbiol. 2008, 46, 2630-2634.

129. Bouwknegt, M.; Rutjes, S.A.; Reusken, C.B.; Stockhofe-Zurwieden, N.; Frankena, K.; de Jong, M.C.; de Roda Husman, A.M.; Poel, W.H. The course of hepatitis E virus infection in pigs after contact-infection and intravenous inoculation. BMC Vet. Res. 2009, 5, doi:10.1186/ 1746-6148-5-7.

130. Williams, T.; Kasorndorkbua, C.; Halbur, P.; Haqshenas, G.; Guenette, D.; Toth, T.; Meng, X. Evidence of extrahepatic sites of replication of the hepatitis E virus in a swine model. J. Clin. Microbiol. 2001, 39, 3040-3046.

131. Miyashita, K.; Kang, J.H.; Saga, A.; Takahashi, K.; Shimamura, T.; Yasumoto, A.; Fukushima, H.; Sogabe, S.; Konishi, K.; Uchida, T.; et al. Three cases of acute or fulminant hepatitis E caused by ingestion of pork meat and entrails in Hokkaido, Japan: Zoonotic food-borne transmission of hepatitis E virus and public health concerns. Hepatol. Res. 2012, 42, 870-878.

132. Li, T.C.; Chijiwa, K.; Sera, N.; Ishibashi, T.; Etoh, Y.; Shinohara, Y.; Kurata, Y.; Ishida, M.; Sakamoto, S.; Takeda, N.; et al. Hepatitis E virus transmission from wild boar meat. Emerg. Infect. Dis. 2005, 11, 1958-1960.

133. Matsuda, H.; Okada, K.; Takahashi, K.; Mishiro, S. Severe hepatitis E virus infection after ingestion of uncooked liver from a wild boar. J. Infect. Dis. 2003, 188, 944, doi:10.1086/378074.

134. Tamada, Y.; Yano, K.; Yatsuhashi, H.; Inoue, O.; Mawatari, F.; Ishibashi, H. Consumption of wild boar linked to cases of hepatitis E. J. Hepatol. 2004, 40, 869-870.

135. Hijioka, S.; Sato, Y.; Iwashita, Y.; Indou, Y. A case of acute hepatitis E who had a history of frequent ingestion of raw meat and viscera from wild deer and boars. Nihon Shokakibyo. Gakkai. Zasshi 2005, 102, 723-728, in Japanese.

136. Martelli, F.; Caprioli, A.; Zengarini, M.; Marata, A.; Fiegna, C.; di Bartolo, I.; Ruggeri, F.; Delogu, M.; Ostanello, F. Detection of hepatitis E virus (HEV) in a demographic managed wild boar (Sus scrofa scrofa) population in Italy. Vet. Microbiol. 2008, 126, 74-81. 
137. Kaba, M.; Davoust, B.; Marié, J.L.; Colson, P. Detection of hepatitis E virus in wild boar (Sus scrofa) livers. Vet. J. 2010, 186, 259-261.

138. Wichmann, O.; Schimanski, S.; Koch, J.; Kohler, M.; Rothe, C.; Plentz, A.; Jilg, W.; Stark, K. Phylogenetic and case-control study on hepatitis E virus infection in Germany. J. Infect. Dis. 2008, 198, 1732-1741.

139. Sonoda, H.; Abe, M.; Sugimoto, T.; Sato, Y.; Bando, M.; Fukui, E.; Mizuo, H.; Takahashi, M.; Nishizawa, T.; Okamoto, H. Prevalence of hepatitis E virus (HEV) Infection in wild boars and deer and genetic identification of a genotype $3 \mathrm{HEV}$ from a boar in Japan. J. Clin. Microbiol. 2004, 42, 5371-5374.

140. Christou, L.; Kosmidou, M. Hepatitis E virus in the Western world-a pork-related zoonosis. Clin. Microbiol. Infect. 2013, 19, 600-604.

141. Berto, A.; Grierson, S.; Hakze-van der Honing, R.; Martelli, F.; Johne, R.; Reetz, J.; Ulrich, R.; Pavio, N.; van der Poel, W.; Banks, M. Hepatitis E virus in pork liver sausage, France. Emerg. Infect. Dis. 2013, 19, 264-266.

142. Wenzel, J.J.; Preiss, J.; Schemmerer, M.; Huber, B.; Plentz, A.; Jilg, W. Detection of hepatitis E virus (HEV) from porcine livers in Southeastern Germany and high sequence homology to human HEV isolates. J. Clin. Virol. 2011, 52, 50-54.

143. Bouwknegt, M.; Lodder-Verschoor, F.; van der Poel, W.; Rutjes, S.; de Roda Husman, A. Hepatitis E virus RNA in commercial porcine livers in The Netherlands. J. Food. Protect. 2007, 70, 2889-2895.

144. Feagins, A.R.; Opriessnig, T.; Guenette, D.K.; Halbur, P.G.; Meng, X.J. Detection and characterization of infectious Hepatitis E virus from commercial pig livers sold in local grocery stores in the USA. J. Gen. Virol. 2007, 88, 912-917.

145. Wacheck, S.; Werres, C.; Mohn, U.; Dorn, S.; Soutschek, E.; Fredriksson-Ahomaa, M.; Märtlbauer, E. Detection of $\operatorname{IgM}$ and $\operatorname{IgG}$ against hepatitis E virus in serum and meat juice samples from pigs at slaughter in Bavaria, Germany. Foodborne. Pathog. Dis. 2012, 9, 655-660.

146. Di Bartolo, I.; Ponterio, E.; Castellini, L.; Ostanello, F.; Ruggeri, F.M. Viral and antibody HEV prevalence in swine at slaughterhouse in Italy. Vet. Microbiol. 2011, 149, 330-338.

147. Di Bartolo, I.; Diez-Valcarce, M.; Vasickova, P.; Kralik, P.; Hernandez, M.; Angeloni, G.; Ostanello, F.; Bouwknegt, M.; Rodríguez-Lázaro, D.; Pavlik, I.; et al. Hepatitis E virus in pork production chain in Czech Republic, Italy, and Spain, 2010. Emerg. Infect. Dis. 2010, 18, 1282 1289.

148. Kulkarni, M.A.; Arankalle, V.A. The detection and characterization of hepatitis E virus in pig livers from retail markets of India. J. Med. Virol. 2008, 80, 1387-1390.

149. Shukla, P.; Chauhan, U.K.; Naik, S.; Anderson, D.; Aggarwal, R. Hepatitis E virus infection among animals in northern India: An unlikely source of human disease. J. Viral Hepat. 2007, 14, $310-317$.

150. Tomiyama, D.; Inoue, E.; Osawa, Y.; Okazaki, K. Serological evidence of infection with hepatitis E virus among wild Yezo-deer, Cervus nippon yesoensis, in Hokkaido, Japan. J. Viral Hepat. 2009, 16, 524-528. 
151. Tei, S.; Kitajima, N.; Ohara, S.; Inoue, Y.; Miki, M.; Yamatani, T.; Yamabe, H.; Mishiro, S.; Kinoshita, Y. Consumption of uncooked deer meat as a risk factor for hepatitis E virus infection: An age- and sex-matched case-control study. J. Med. Virol. 2004, 74, 67-70.

152. Legrand-Abravanel, F.; Kamar, N.; Sandres-Saune, K.; Garrouste, C.; Dubois, M.; Mansuy, J.M.; Muscari, F.; Sallusto, F.; Rostaing, L.; Izopet, J. Characteristics of autochthonous hepatitis E virus infection in solid-organ transplant recipients in France. J. Infect. Dis. 2010, 202, 835-844.

153. Geng, Y.; Zhao, C.; Song, A.; Wang, J.; Zhang, X.; Harrison, T.; Zhou, Y.; Wang, W.; Wang, Y. The serological prevalence and genetic diversity of hepatitis E virus in farmed rabbits in China. Infect. Genet. Evol. 2011, 11, 476-482.

154. Sanford, B.; Emerson, S.; Purcell, R.; Engle, R.; Dryman, B.; Cecere, T.; Buechner-Maxwell, V.; Sponenberg, D.; Meng, X.J. Serological evidence for a hepatitis E virus-related agent in goats in the United States. Transbound. Emerg. Dis. 2012, doi:10.1111/tbed.12001.

155. Haqshenas, G.; Huang, F.F.; Fenaux, M.; Guenette, D.K.; Pierson, F.W.; Larsen, C.T.; Shivaprasad, H.L.; Toth, T.E.; Meng, X.J. The putative capsid protein of the newly identified avian hepatitis E virus shares antigenic epitopes with that of swine and human hepatitis E viruses and chicken big liver and spleen disease virus. J. Gen. Virol. 2002, 83, 2201-2209.

156. Bilic, I.; Jaskulska, B.; Basic, A.; Morrow, C.; Hess, M. Sequence analysis and comparison of avian hepatitis E viruses from Australia and Europe indicate the existence of different genotypes. J. Gen. Virol. 2009, 90, 863-873.

157. Zhao, Q.; Sun, Y.; Zhao, J.; Hu, S.; Zhao, F.; Chen, F.; Clavijo, A.; Zhou, E.M.; Xiao, Y. Development and application of an indirect ELISA for detection of antibodies against avian hepatitis E virus. J. Virol. Methods. 2013, 187, 32-36.

158. Sato, Y.; Sato, H.; Naka, K.; Furuya, S.; Tsukiji, H.; Kitagawa, K.; Sonoda, Y.; Usui, T.; Sakamoto, H.; Yoshino, S.; et al. A nationwide survey of hepatitis E virus (HEV) infection in wild boars in Japan: Identification of boar HEV strains of genotypes 3 and 4 and unrecognized genotypes. Arch. Virol. 2011, 156, 1345-1358.

159. Takahashi, M.; Nishizawa, T.; Tanaka, T.; Tsatsralt-Od, B.; Inoue, J.; Okamoto, H. Correlation between positivity for immunoglobulin $\mathrm{A}$ antibodies and viraemia of swine hepatitis $\mathrm{E}$ virus observed among farm pigs in Japan. J. Gen. Virol. 2005, 86, 1807-1813.

160. Rutjes, S.A.; Lodder, W.J.; Bouwknegt, M.; de Roda Husman, A.M. Increased hepatitis E virus prevalence on Dutch pig farms from 33 to $55 \%$ by using appropriate internal quality controls for RT-PCR. J. Virol. Methods 2007, 143, 112-116.

161. Seminati, C.; Mateu, E.; Peralta, B.; de Deus, N.; Martin, M. Distribution of hepatitis E virus infection and its prevalence in pigs on commercial farms in Spain. Vet. J. 2008, 175, 130-132.

162. Garkavenko, O.; Obriadina, A.; Meng, J.; Anderson, D.A.; Benard, H.J.; Schroeder, B.A.; Khudyakov, Y.E.; Fields, H.A.; Croxson, M.C. Detection and characterisation of swine hepatitis E virus in New Zealand. J. Med. Virol. 2001, 65, 525-529.

163. Blacksell, S.D.; Myint, K.S.; Khounsy, S.; Phruaravanh, M.; Mammen, M.P., Jr.; Day, N.P.; Newton, P.N. Prevalence of hepatitis E virus antibodies in pigs: Implications for human infections in village-based subsistence pig farming in the Lao PDR. Trans. Roy. Soc. Trop. Med. Hyg. 2007, 101, 305-307. 
164. Dos Santos, D.R.; Vitral, C.L.; de Paula, V.S.; Marchevsky, R.S.; Lopes, J.F.; Gaspar, A.M.; Saddi, T.M.; Junior, N.C.; Guimaraes Fde, R.; Junior, J.G.; et al. Serological and molecular evidence of hepatitis E virus in swine in Brazil. Vet. J. 2009, 182, 474-480.

165. Reuter, G.B.; Fodor, D.; Forgách, P.; Kátai, A.; Szucs, G. Characterization and zoonotic potential of endemic hepatitis E virus (HEV) strains in humans and animals in Hungary. J. Clin. Virol. 2009, 44, 277-281.

166. Schielke, A.; Sachs, K.; Lierz, M.; Appel, B.; Jansen, A.; Johne, R. Detection of hepatitis E virus in wild boars of rural and urban regions in Germany and whole genome characterization of an endemic strain. Virol. J. 2009, 6, doi:10.1186/1743-422X-6-58.

167. Forgach, P.; Nowotny, N.; Erdelyi, K.; Boncz, A.; Zentai, J.; Szucs, G.; Reuter, G.; Bakonyi, T. Detection of hepatitis E virus in samples of animal origin collected in Hungary. Vet. Microbiol. 2010, 143, 106-116.

168. Matsuura, Y.; Suzuki, M.; Yoshimatsu, K.; Arikawa, J.; Takashima, I.; Yokoyama, M.; Igota, H.; Yamauchi, K.; Ishida, S.; Fukui, D.; et al. Prevalence of antibody to hepatitis E virus among wild sika deer, Cervus nippon, in Japan. Arch. Virol. 2007, 152, 1375-1381.

169. Rutjes, S.A.; Lodder-Verschoor, F.; Lodder, W.J.; van der Giessen, J.; Reesink, H.; Bouwknegt, M.; de Roda Husman, A.M. Seroprevalence and molecular detection of hepatitis E virus in wild boar and red deer in The Netherlands. J. Virol. Methods 2010, 168, 197-206.

170. Medrano, C.; Boadella, M.; Barrios, H.; Cantu, A.; Garcia, Z.; de la Fuente, J.; Gortazar, C. Zoonotic pathogens among white-tailed deer, northern Mexico, 2004-2009. Emerg. Infect. Dis. 2012, 18, 1372-1374.

171. El-Tras, W.F.; Tayel, A.A.; El-Kady, N.N. Seroprevalence of hepatitis E virus in humans and geographically matched food animals in Egypt. Zoonoses Public Health 2012, 60, 244-251.

172. Arankalle, V.; Joshi, M.; Kulkarni, A.; Gandhe, S.; Chobe, L.; Rautmare, S.; Mishra, A.; Padbidri, V. Prevalence of anti-hepatitis E virus antibodies in different Indian animal species. J. Viral Hepat. 2001, 8, 223-227.

173. Vitral, C.L.; Pinto, M.A.; Lewis-Ximenez, L.L.; Khudyakov, Y.E.; dos Santos, D.R.; Gaspar, A.M. Serological evidence of hepatitis E virus infection in different animal species from the Southeast of Brazil. Mem. Inst. Oswaldo. Cruz. 2005, 100, 117-122.

174. Geng, Y.; Wang, C.; Zhao, C.; Yu, X.; Harrison, T.J.; Tian, K.; Wang, Y. Serological prevalence of hepatitis $\mathrm{E}$ virus in domestic animals and diversity of genotype 4 hepatitis $\mathrm{E}$ virus in China. Vector Borne Zoonotic. Dis. 2010, 10, 765-770.

175. Yu, Y.; Sun, J.; Liu, M.; Xia, L.; Zhao, C.; Harrison, T.J.; Wang, Y. Seroepidemiology and genetic characterization of hepatitis E virus in the northeast of China. Infect. Genet. Evol. 2009, 9, 554-561.

176. Zhang, W.; Shen, Q.; Mou, J.; Gong, G.; Yang, Z.; Cui, L.; Zhu, J.; Ju, G.; Hua, X. Hepatitis E virus infection among domestic animals in eastern China. Zoonoses Public Heslth 2008, 55, 291-298.

177. Meng, X.J. Swine hepatitis E virus: Cross-species infection and risk in xenotransplantation. In Xeno-transplantation; Salomon, D.R., Wilson, C., Eds; Springer: Berlin, Germany, 2003; pp. 185-216. 
178. Kabrane-Lazizi, Y.; Fine, J.B.; Elm, J.; Glass, G.E.; Higa, H.; Diwan, A.; Gibbs, C.J., Jr.; Meng, X.J.; Emerson, S.U.; Purcell, R.H. Evidence for widespread infection of wild rats with hepatitis E virus in the United States. Am. J. Trop. Med. Hyg. 1999, 61, 331-335.

179. Hirano, M.; Ding, X.; Li, T.C.; Takeda, N.; Kawabata, H.; Koizumi, N.; Kadosaka, T.; Goto, I.; Masuzawa, T.; Nakamura, M.; et al. Evidence for widespread infection of hepatitis E virus among wild rats in Japan. Hepatol. Res. 2003, 27, 1-5.

180. Li, W.; Guan, D.; Su, J.; Takeda, N.; Wakita, T.; Li, T.C.; Ke, C.W. High prevalence of rat hepatitis E virus in wild rats in China. Vet. Microbiol. 2013, 165, 275-280.

181. Mulyanto; Depamede, S.N.; Sriasih, M.; Takahashi, M.; Nagashima, S.; Jirintai, S.; Nishizawa, T.; Okamoto, H. Frequent detection and characterization of hepatitis E virus variants in wild rats (Rattus rattus) in Indonesia. Arch. Virol. 2013, 158, 87-96.

182. Lack, J.; Volk, K.; van den Bussche, R. Hepatitis E virus genotype 3 in wild rats, United States. Emerg. Infect. Dis. 2012, 18, 1268-1273.

183. Favorov, M.O.; Kosoy, M.Y.; Tsarev, S.A.; Childs, J.E.; Margolis, H.S. Prevalence of antibody to hepatitis E virus among rodents in the United States. J. Infect. Dis. 2000, 181, 449-455.

184. Li, T.C.; Ami, Y.; Suzaki, Y.; Takeda, N.; Takaji, W. No evidence for hepatitis E virus genotype 3 susceptibility in rats. Emerg. Infect. Dis. 2013, 19, 1343-1345.

185. Izopet, J.; Dubois, M.; Bertagnoli, S.; Lhomme, S.; Marchandeau, S.; Boucher, S.; Kamar, N.; Abravanel, F.; Guerin, J.L. Hepatitis E virus strains in rabbits and evidence of a closely related strain in humans, France. Emerg. Infect. Dis. 2012, 18, 1274-1281.

186. Cossaboom, C.M.; Cordoba, L.; Sanford, B.J.; Pineyro, P.; Kenney, S.P.; Dryman, B.A.; Wang, Y.; Meng, X.J. Cross-species infection of pigs with a novel rabbit, but not rat, strain of hepatitis $\mathrm{E}$ virus isolated in the United States. J. Gen. Virol. 2012, 93, 1687-1695.

187. Li, T.C.; Saito, M.; Ogura, G.; Ishibashi, O.; Miyamura, T.; Takeda, N. Serologic evidence for hepatitis E virus infection in mongoose. Am. J. Trop. Med. Hyg. 2006, 74, 932-936.

188. Nakamura, M.; Takahashi, K.; Taira, K.; Taira, M.; Ohno, A.; Sakugawa, H.; Arai, M.; Mishiro, S. Hepatitis E virus infection in wild mongooses of Okinawa, Japan: Demonstration of anti-HEV antibodies and a full-genome nucleotide sequence. Hepatol. Res. 2006, 34, 137-140.

189. Meng, X.J.; Wiseman, B.; Elvinger, F.; Guenette, D.; Toth, T.; Engle, R.; Emerson, S.; Purcell, R. Prevalence of antibodies to hepatitis $\mathrm{E}$ virus in veterinarians working with swine and in normal blood donors in the United States and other countries. J. Clin. Microbiol. 2002, 40, 117-122.

190. Meng, X.J.; Dea, S.; Engle, R.E.; Friendship, R.; Lyoo, Y.S.; Sirinarumitr, T.; Urairong, K.; Wang, D.; Wong, D.; Yoo, D.; et al. Prevalence of antibodies to the hepatitis E virus in pigs from countries where hepatitis $\mathrm{E}$ is common or is rare in the human population. J. Med. Virol. 1999, 59, 297-302.

191. Withers, M.; Correa, M.; Morrow, M.; Stebbins, M.; Seriwatana, J.; Webster, W.; Boak, M.; Vaughn, D. Antibody levels to hepatitis E virus in North Carolina swine workers, non-swine workers, swine, and murids. Am. J. Trop. Med. Hyg. 2002, 66, 384-388.

192. Drobeniuc, J.; Favorov, M.; Shapiro, C.; Bell, B.; Mast, E.; Dadu, A.; Culver, D.; Iarovoi, P.; Robertson, B.; Margolis, H. Hepatitis E virus antibody prevalence among persons who work with swine. J. Infect. Dis. 2001, 184, 1594-1597. 
193. Karetnyi, Y.V.; Gilchrist, M.J.; Naides, S.J. Hepatitis E virus infection prevalence among selected populations in Iowa. J. Clin. Virol. 1999, 14, 51-55.

(C) 2013 by the authors; licensee MDPI, Basel, Switzerland. This article is an open access article distributed under the terms and conditions of the Creative Commons Attribution license (http://creativecommons.org/licenses/by/3.0/). 